\title{
A DRIVING ADAPTATION FOR TRIPLEGIC PERSONS AND A TRAVELLING ADAPTATION DEVICE FOR PARAPLEGIC PERSONS *
}

\author{
By P. Dollfus, M.D., J. M. Ball, M.D., R. Zimmermann, M.D., \\ and J. Chaudron, M.D. \\ Centre de Readaptation, Mulhouse, France.
}

Summary. A simple system is described which allows a person with a complete paralysis of the lower limbs and the use of only one arm to drive. Another system, portable, allows a paraplegic person to adapt an automatic rented car in a very short time and thus enhances the possibilities of independence.

Key words: Triplegia; Paraplegia; Driving adaptations.

FRENCH legislation does not forbid a triplegic person from driving, provided he passes an official medical aptitude examination and, if necessary, a specialist consultation. Possibilities of appeal can be sought at Regional and National level.

For many years at the Rehabilitation Centre of Mulhouse the problem of driving for disabled persons has been considered as an important aid for social and vocational reintegration. This has been specially developed in our vocational evaluation and follow-up department in collaboration with the medical rehabilitation unit. It is multidisciplinary work and includes a private driving school which has been associated with the Centre for more than 2 I years.

Updating is costly and cannot always be complete. Most of the published research is either under development, often not commercially available, or beyond the usual financial means. The rapidity of technological advances is nowadays such that it can deter many potential buyers from purchasing elaborate devices apart from the pure financial aspects. Concerning research and development, several firms and rehabilitation engineers have achieved technological wonders. A constant dialogue and a co-operation between technology for all people, and more specialized for disabled people, should be encouraged. Several examples of research are now known, such as Mobility Engineering, California; in Sweden $A b$ Teknik working with the Handikappinstitute; and in France the association of Renault with the Inserm in Montpellier. These are some examples and we know that many other research projects are underway. Recently a voicecontrolled car is under development and has been presented to the public through the media of television. From a practical point of view the problem of servicing such devices after a few years is quite acute. In France, very few people get their driving equipment free of charge. Most require to

$\star$ Read at the Annual Meeting of the International Medical Society of Paraplegia, Stoke Mandeville Hospital, Aylesbury, Bucks., England. July I98I. 
pay for the equipment, the installation and also for the 17.6 per cent V.A.T. tax. Therefore, it is understandable that they wish to retain their equipment to be used on a subsequent car.

We have successfully used 'the Israeli shoulder system', which was invented a few years ago in Israel, and is also used with some modifications in Western Germany and in Switzerland (Münz and Zawatzky, I979) and in Switzerland (Wider, I978). This system allows movements of the scapula on the side to brake by pushing forwards and to accelerate by a backward movement of the shoulder. The braking system must be assisted by a modification of the 'mastervac' system which is also used for our tetraplegic patients.

Our disabled people have an extensive test before being advised on the apparatus to use during their driving lessons. We estimate that, in most cases, the evaluation of the disabled person's possibilities is far better 'on the road' rather than by different psychological technical tests performed in a laboratory.

We wish to present two cases with spinal cord involvement who have been taught how to use this system with success.

\section{Case Reports}

Case I. A 22-year-old man, with a complete T6-7 lesion associated with a rightsided complete brachial plexus lesion. He is right handed. He learned by chance that such a system existed, and this led him to ask us for some details. He developed a pressure ulcer elsewhere and was admitted to our Centre on medical grounds, and also for vocational assessment. Before his accident he had

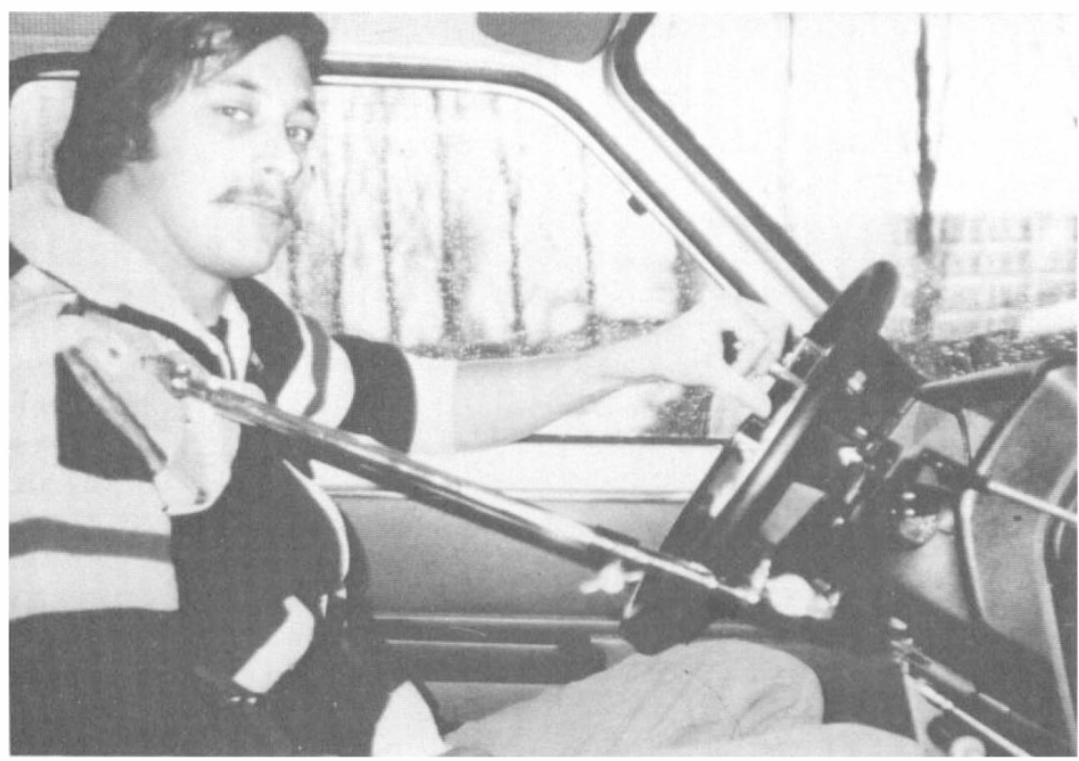

FIG. I

A paraplegic person with right plexus lesion. The steering is done with the left upper limb, braking and acceleration with the right shoulder. 
had a driver's licence for one year. During his stay he had 22 driving lessons as these were needed to adapt himself to the system. In spite of his multiple handicaps he managed to transfer to and from his wheelchair alone and even to take the wheelchair in and out of the car with his left upper limb. $\mathrm{He}$ is now successfully driving a Renault T-I 8 automatic car (Fig. I).

Case 2. A 45-year-old patient with severe poliomyelitis with involvement of his lower limbs and left upper limb. He did not hold a driver's licence, and needed 30 lessons before acquiring his licence. He is now provided with the system as Case I, and is successfully driving a Renault R-5 automatic car. (Fig. 2).

Two other persons, one a tri-amputee and who had had a head injury, have been equipped with a similar system.

Travelling for a paraplegic is sometimes difficult and hiring a car with appropriate adaptations is even more difficult. A new development has taken place in France recently and we would briefly like to present this system which we have been trying at our Centre, and is also under trial in Austria. It comprises a main shaft, which can be quickly adapted, in about is minutes, with a throttle and brake system to the pedals. The shaft is secured to the driver's seat by a special strap, allowing rapid and safe adaptation. It weighs approximately 7

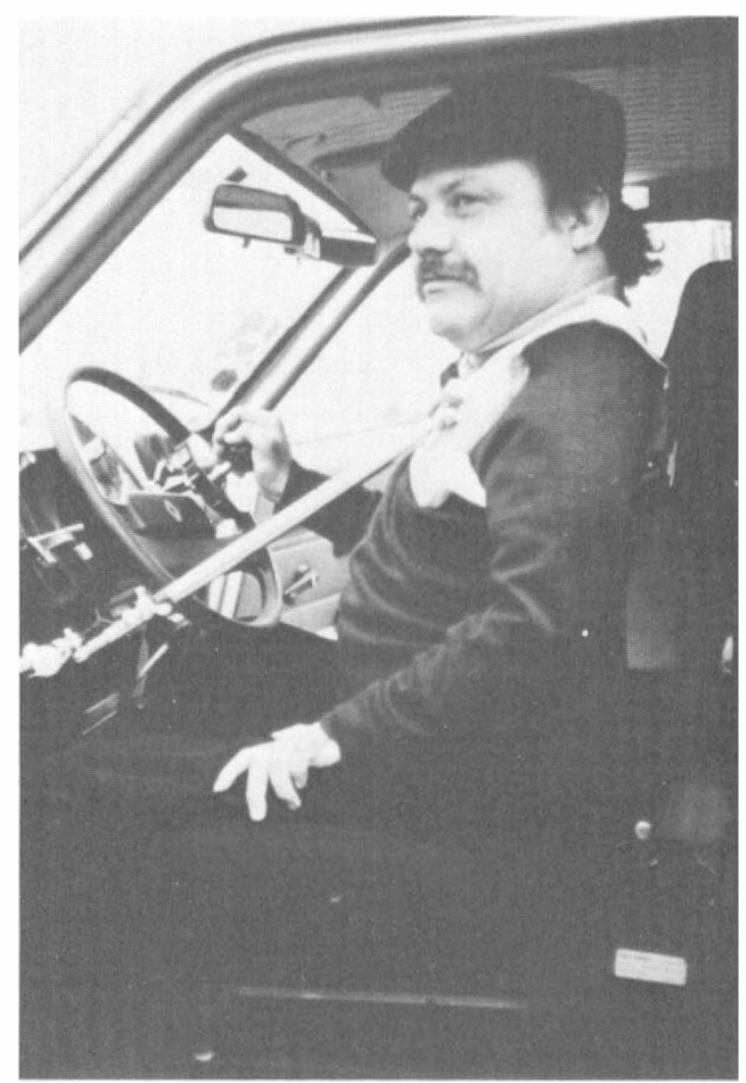

FIG. 2

A person with poliomyelitis affecting both lower limbs and left arm. 
kilos and can be carried in the person's luggage; it can only be used on a car with automatic gears. We think that it is a very interesting development and is completely safe. Unfortunately, insurance problems and national regulations in different countries present problems which must be solved for such provisional systems. These must not be used as permanent systems but will enable disabled people to be totally independent when they are visiting certain countries for work or for pleasure (Fig. 3).

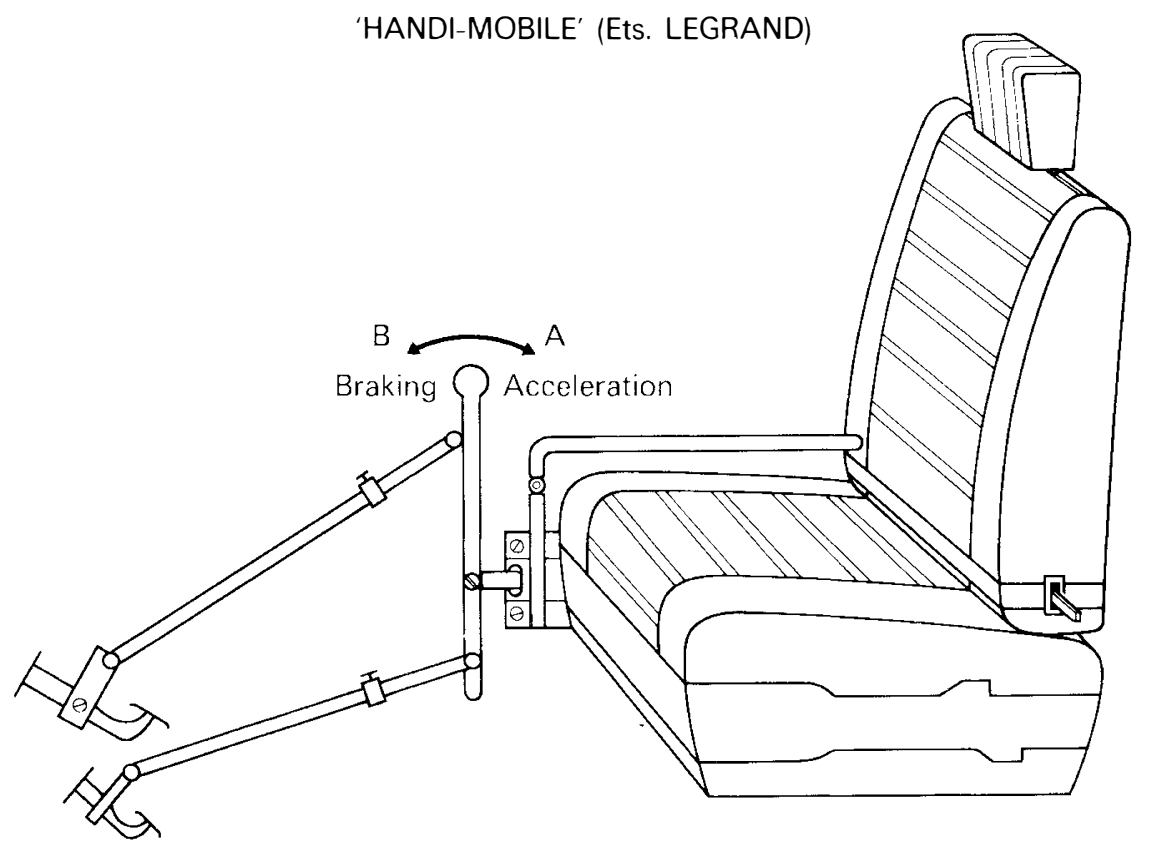

FIG. 3 *

Travel modular system (System Legrand-Paris).

\section{RÉSUMÉ}

Le problème de la conduite automobile pour une personne tri-plégique peut être dans certains cas résolu grâce au système d'origine israélienne. Deux cas sont présentés. Un nouveau système permet à une personne handicapée d'emporter dans ses bagages un système à adapter aux voitures de louage avec changement de vitesse automatique.

\section{ZUSAMMENFASSUNG}

Das problem des Autofahren kann in gewissen Fälle gelöst werden durch ein System das in Israel enstand. Zwei Fälle werden vorgelegt. Weiter, wird ein neues System vorgeführt, welches ein Paraplegiker in seinem Reisegepäck mitnehmen kann und welches auf den meisten Mietwagen die mit automatischem Getriebe ausgestattet sind, anpassbar ist.

\section{REFERENCES}

MÜNZ, M. \& ZAWATZKY, R. (1979). Kraftfahrzeugversorgung für Mehrfachbehinderte. Medizinisch-Orthopädische Technik, 99, I 74-I 76.

WIDER, H. (1978). Körperbehinderte als Motorfahrzeuglenker. Wegleitung zur Motorisierung invalider Personen. Strassenverkehrsamt des Kantons Zürich, Zürich. 